\title{
OPEN Cell cycle dependence of apoptosis photo-triggered using peptide-photosensitizer conjugate
}

\author{
Hyungjin $\mathrm{Kim}^{1,3}$, Sho Watanabe ${ }^{1}$, Mizuki Kitamatsu ${ }^{2}$, Kazunori Watanabe ${ }^{1}$ \& \\ Takashi Ohtsuki ${ }^{1 凶}$
}

Investigation of the relevance between cell cycle status and the bioactivity of exogenously delivered biomacromolecules is hindered by their time-consuming cell internalization and the cytotoxicity of transfection methods. In this study, we addressed these problems by utilizing the photochemical internalization $(\mathrm{PCl})$ method using a peptide/protein-photosensitizer conjugate, which enables immediate cytoplasmic internalization of the bioactive peptides/proteins in a light-dependent manner with low cytotoxicity. To identify the cell-cycle dependent apoptosis, a TatBim peptidephotosensitizer conjugate (TatBim-PS) with apoptotic activity was photo-dependently internalized into HeLa cells expressing a fluorescent ubiquitination-based cell cycle indicator (Fucci2). Upon irradiation, cytoplasmic TatBim-PS internalization exceeded $95 \%$ for all cells classified in the $G_{1}, S_{1}$ and $\mathrm{G}_{2} / \mathrm{M}$ cell cycle phases with no significant differences between groups. TatBim-PS-mediated apoptosis was more efficiently triggered by photoirradiation in the $G_{1} / S$ transition than in the $G_{1}$ and $S / G_{2} / M$ phases, suggesting high sensitivity of the former phase to Bim-induced apoptosis. Thus, the cell cycle dependence of Bim peptide-induced apoptosis was successfully investigated using Fucci2 indicator and the $\mathrm{PCI}$ method. Since $\mathrm{PCl}$-mediated cytoplasmic internalization of peptides is rapid and does not span multiple cell cycle phases, the Fucci-PCI method constitutes a promising tool for analyzing the cell cycle dependence of peptides/protein functions.

The eukaryotic cell cycle is divided into gap $1\left(G_{1}\right)$, synthesis $(S)$, gap $2\left(G_{2}\right)$, and mitotic $(M)$ phases. The cell cycle dependence of various cell functions has long attracted considerable research attention. For example, the cell cycle dependence of antigen protein expression ${ }^{1}, \mathrm{Ca}^{2+}$ oscillation $^{2}$, cell differentiation ${ }^{3}$, and cellular body formation ${ }^{4}$ has been evaluated. In addition, numerous researchers have studied the cell cycle dependence of cell fates induced by X-ray ${ }^{5}$, heat ${ }^{6}$, and drugs/chemicals ${ }^{7,8}$.

In contrast to cell permeable drugs/chemicals, investigation of the cell cycle dependence of cell fates induced by cell-impermeable peptides/proteins has been challenging because the most of peptide/protein transduction ${ }^{9}$ or peptide/protein gene transfection ${ }^{10}$ methodologies are time-consuming and the cell cycle is likely to progress to the next phase during these extended transduction or transfection procedures. In addition, the gene expression obtained following gene transfection is likely to continue throughout several cell cycle phases. In cultured mammalian cells, each cell cycle phase tends to last for tens of minutes to several hours ${ }^{8,11}$; for example, HeLa cells spend approximately $4.6 \mathrm{~h}$ in $\mathrm{G}_{1}$ phase, $6.0 \mathrm{~h}$ in $\mathrm{S}$ phase, $3.1 \mathrm{~h}$ in $\mathrm{G}_{2}$ phase, and $0.7 \mathrm{~h}$ in $\mathrm{M}$ phase; mouse embryonic stem cells spend approximately $1.0,5.9,2.7$, and $0.6 \mathrm{~h}$ in the respective phases. Therefore, to investigate peptide/protein function during a specific cell cycle phase, a rapid peptide/protein transduction method is necessary. However, although electroporation and microinjection fulfill this requirement, the damage associated with the electrical stimulation or injection ${ }^{12}$ render it difficult to observe natural cellular responses immediately following the transduction.

As an alternative, the photochemical internalization (PCI) method, which enables rapid cytoplasmic introduction ( $<5$ min after light irradiation) of a peptide/protein ${ }^{13-19}$, shows promise for investigating peptide/protein function in a specific cell cycle phase. PCI constitutes a method for inducing the light-directed endosomal escape (and cytoplasmic release) of macromolecules, which are delivered into cells through endocytosis and entrapped in endosomes ${ }^{20,21}$. In this method, endosomal membranes are destabilized by singlet oxygen photogenerated

\footnotetext{
${ }^{1}$ Department of Interdisciplinary Science and Engineering in Health Systems, Okayama University, 3-1-1 Tsushimanaka, Okayama 700-8530, Japan. ²Department of Applied Chemistry, Kindai University, 3-4-1 Kowakae, Higashi-Osaka, Osaka 577-8502, Japan. ${ }^{3}$ Present address: Department of Organ Anatomy and Nanomedicine, Yamaguchi University, 1-1-1 Minami-Kogushi, Ube 755-8505, Japan. ${ }^{\circledR}$ email: ohtsuk@okayama-u.ac.jp
} 
A

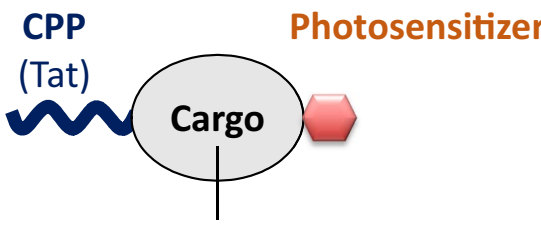

\section{Peptide/protein of interest}

(Bim peptide)

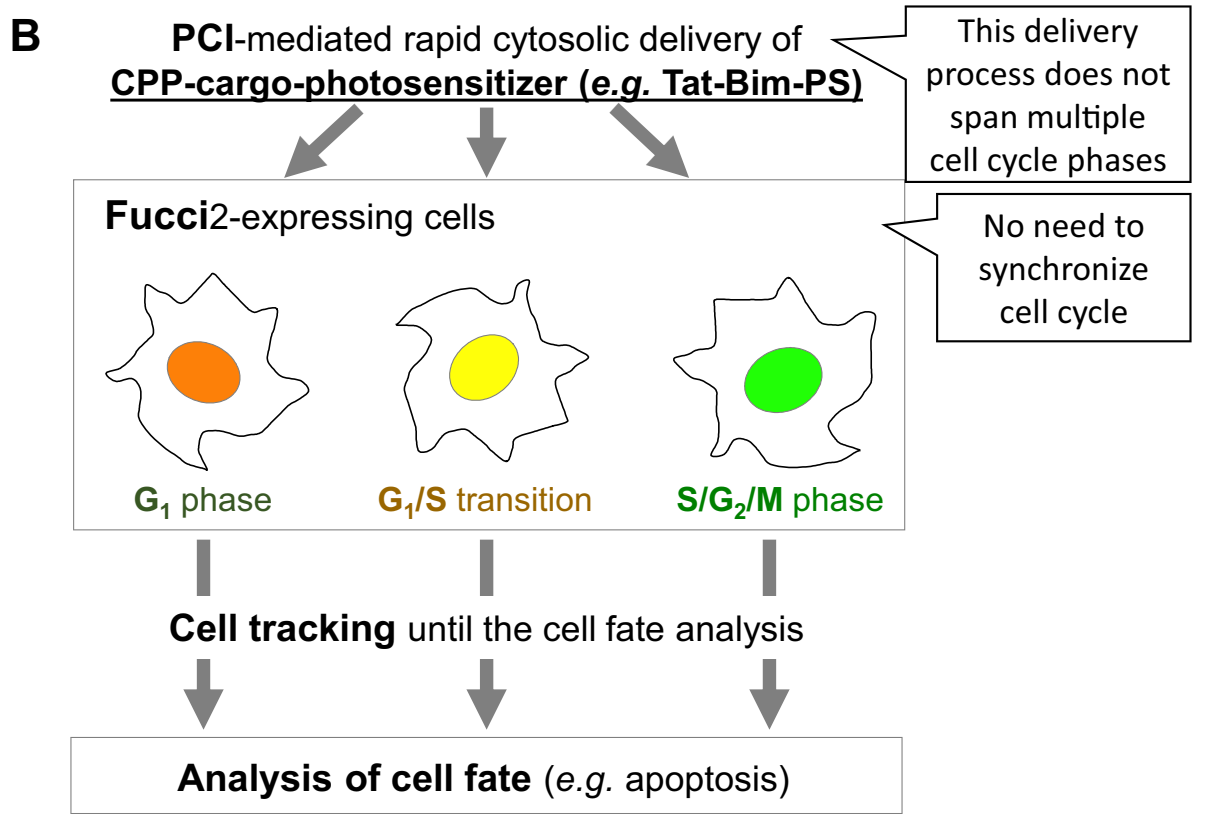

Figure 1. A CPP-cargo-photosensitizer conjugate and the Fucci-PCI method. (A) Design of a CPP-cargophotosensitizer conjugate for PCI-mediated cytoplasmic peptide/protein delivery. The CPP, cargo, and photosensitizer used in this study are shown in parentheses. (B) A schematic overview of the Fucci-PCI method.

from photosensitizers ${ }^{13,22,23}$. For PCI-mediated peptide/protein delivery, cell penetrating peptide (CPP)-cargophotosensitizer conjugates, in which cargo represents a peptide/protein of interest, can be used (Fig. 1A) ${ }^{24-26}$. Notably, through the use of photosensitizers with low singlet oxygen quantum yield combined with minimum light dose, photocytotoxicity can be very low ${ }^{27}$.

In this study, we investigated the relationship between the cell cycle and apoptosis induced by the Bim peptide delivered using the PCI method. Specifically, Bim peptide constitutes the BH3 domains of the Bim apoptosisinducing protein, which serves as the biological effector domain ${ }^{28,29}$. For PCI, we used TatBim-PS ${ }^{25,30}$ (Fig. 1), a fusion molecule of the TAT cell-penetrating peptide ${ }^{31,32}$, the Bim peptide, and the photosensitizer Alexa Fluor 633 (Alexa633). The cell cycle was monitored using a fluorescent ubiquitination-based cell cycle indicator 2 (Fucci2) probe ${ }^{33}$. Here, we provide a new method for investigating the cell cycle dependence of peptide/protein function using Fucci2 imaging and rapid PCI-mediated cytoplasmic delivery of the peptide/protein (Fucci-PCI method) (Fig. 1B). This method enables investigation of the relationship between cell cycle phases and fate of the PCI-treated cells without necessitating a cell cycle-synchronization process. The novelty of this study lies in the combination of Fucci2-expressing cells that visualize some cell cycle states and the conjugated peptide that potentially shows a cell cycle-specific biological activity.

\section{Methods}

Preparation of the photosensitizer-conjugated TatBim (TatBim-PS). TatBim peptide with a cysteine residue at the C-terminus (RKKRRQRRR-EIWIAQELRRIGDEFNAYYARLL-C) was prepared by solid-phase peptide synthesis using standard Fmoc protocols. Alexa Fluor 633 C5 maleimide (Life Technologies, Carlsbad, CA, USA), a photosensitizer, was then attached to the thiol group of the C-terminal Cys of the TatBim peptide. This reaction was performed at a peptide:Alexa633 molar ratio of 1:2 in dimethylformamide at $37^{\circ} \mathrm{C}$ for $2 \mathrm{~h}$. TatBim-PS (TatBim-Alexa633) was purified from the reaction mixture by reversed-phase high performance liquid chromatography (HPLC) on a C18 column using a linear 0-100\% gradient of acetonitrile in $0.1 \%$ trifluoracetic acid (Fig. S1). 

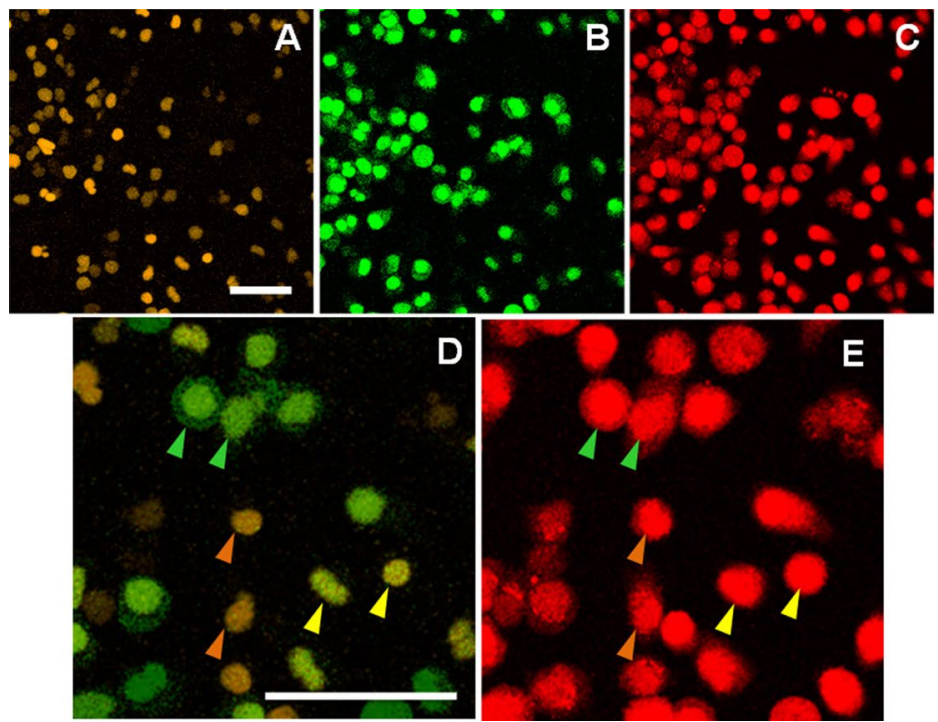

$\mathbf{F}$

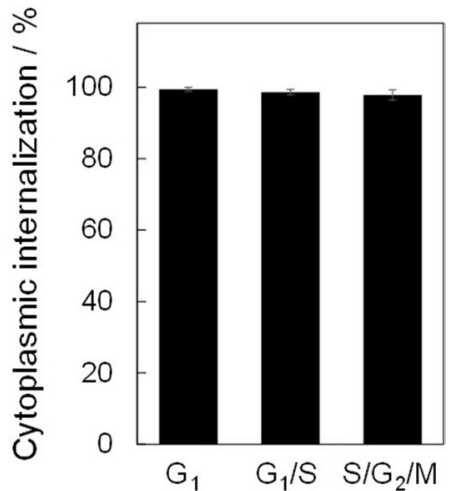

Figure 2. Efficient internalization of TatBim-PS by HeLa/Fucci2 cells irrespective of cell-cycle phase. (A-C) Fluorescence images of the mCherry-human Cdt1 fusion protein (mCherry-hCdt1) showing $G_{1}$ and $G_{1} / S$ transition phases (A), mVenus-human Geminine fusion protein (mVenus-hGem) showing $\mathrm{S} / \mathrm{G}_{2} / \mathrm{M}$ phase (B), and TatBim-PS (C). The fluorescence of mCherry (emission maximum around $610 \mathrm{~nm}$ ) was pseudo-colored as orange to distinguish it from the red fluorescence of TatBim-PS (PS = Alexa633; emission maximum at around $650 \mathrm{~nm}$ ). Scale bar, $50 \mu \mathrm{m}$. (D) Magnified, merged image of A and B. Green arrows: $S / G_{2} / M$, Orange arrows: $G_{1}$, and, Yellow arrows: $G_{1} / S$ transition. Scale bar, $50 \mu \mathrm{m}$. (E) Magnified image of $C$. The arrows indicate the same cell cycle phases as in D, with identical color scheme. (F) Cytoplasmic internalization efficiency at each cellcycle. Data are shown as the mean $\pm \operatorname{SEM}(\mathrm{n}=3$; each of the analyzed areas included 117 cells on average).

Photoinduced cytoplasmic dispersion of TatBim-PS at specific cell-cycle phases. HeLa/Fucci2 cells $^{33}$ were purchased from RIKEN BioResource Research Center (Tsukuba, Ibaraki, Japan). The cells were seeded at $2.0 \times 10^{4}$ cells/well in 96 well plates and cultured overnight in RPMI 1640 medium supplemented with $10 \%$ fetal bovine serum (Sigma, St. Louis, MO, USA), $100 \mathrm{U} / \mathrm{mL}$ penicillin and $100 \mu \mathrm{g} / \mathrm{mL}$ streptomycin. The cells were then treated with $2 \mu \mathrm{M}$ TatBim-PS for $2 \mathrm{~h}$ at $37^{\circ} \mathrm{C}$ in serum-free RPMI 1640 medium. After washing twice with the serum-free medium, the cells in the medium were photoirradiated at $620 \pm 25 \mathrm{~nm}$ at a fluence of $40 \mathrm{~J} / \mathrm{cm}^{2}$ with a $100 \mathrm{~W}$ mercury lamp (U-LH100HG, Olympus, Tokyo, Japan)) passed through the Cy5 mirror unit and a $40 \times$ objective lens from a fluorescence microscope (IX51, Olympus). Fluorescence images were acquired using a confocal laser scanning microscope (FLUOVIEW FV1000, Olympus). Fluorescence images were obtained through a $60 \times$ objective lens with the following settings: Alexa633 $\left(\lambda_{\text {ex }}=633 \mathrm{~nm}\right.$, $\left.\lambda_{\mathrm{em}}=655-755 \mathrm{~nm}\right)$, mCherry-hCdt1 $\left(\lambda_{\mathrm{ex}}=543 \mathrm{~nm}, \lambda_{\mathrm{em}}=555-625 \mathrm{~nm}\right)$, and mVenus-hGem $\left(\lambda_{\mathrm{ex}}=488 \mathrm{~nm}\right.$, $\left.\lambda_{\mathrm{em}}=500-530 \mathrm{~nm}\right)$.

The cell cycle of each HeLa/Fucci2 cell was classified into one of three phases according to the Fucci2 color in the cell nucleus: orange/red for $G_{1}$, green for $S / G_{2} / M$, and yellow (merge of both of orange/red and green fluorescence) for $G_{1} / S$ (transition state from $G_{1}$ to $S$ ). The cell cycle phase of each cell was classified using the cellular fluorescence images immediately following the photostimulation (time point $0 \mathrm{~min}$ after irradiation). The photoinduced cytoplasmic internalization efficiencies (\%) of TatBim-PS at the corresponding cell-cycle phases were calculated by counting the number of cells in which Alexa633 fluorescence was dispersed within the cytosol after photostimulation $\left(\mathrm{N}_{\mathrm{AF}}\right)$ and the total cell number of the corresponding cell cycle $\left(\mathrm{N}_{\mathrm{CC}}\right)$. The cytoplasmic internalization efficiency at a given specific cell-cycle phase was defined as $\mathrm{N}_{\mathrm{AF}} / \mathrm{N}_{\mathrm{CC}} \times 100(\%)$.

Evaluation of the cell cycle-dependence of TatBim-PS-induced apoptosis. HeLa/Fucci2 cells were subjected to the same treatment as described above. Following irradiation, the cells were incubated in serum-free RPMI 1640 medium and time-lapse images were obtained every $30 \mathrm{~min}$. The cell cycle phase of each cell was classified using the cellular fluorescence images obtained immediately following the photoirradiation. At $5 \mathrm{~h}$ after photoirradiation, the NucView405 Caspase-3 Substrate (Biotium, Fremont, CA, USA) was added to the medium at a final concentration of $100 \mu \mathrm{M}$ to stain apoptotic cells. Blue fluorescence images were captured beginning at $30 \mathrm{~min}$ after the NucView405 addition using the FLUOVIEW FV1000 confocal laser scanning microscope.

Cell-cycle dependent apoptosis rates (\%) were calculated by counting the number of cells with blue fluorescence (NucView405) at $5.5 \mathrm{~h}$ after photostimulation $\left(\mathrm{N}_{\mathrm{BF}}\right)$ and the $\mathrm{N}_{\mathrm{CC}}$. Cell-cycle dependent apoptosis rate (\%) was defined as $\mathrm{N}_{\mathrm{BF}} / \mathrm{N}_{\mathrm{CC}} \times 100(\%)$.

Cell cycle synchronization with thymidine. HeLa/Fucci2 cells were treated with 2 mM thymidine in RPMI 1640 medium supplemented with $10 \%$ fetal bovine serum for $18 \mathrm{~h}$ for cell cycle synchronization. The 


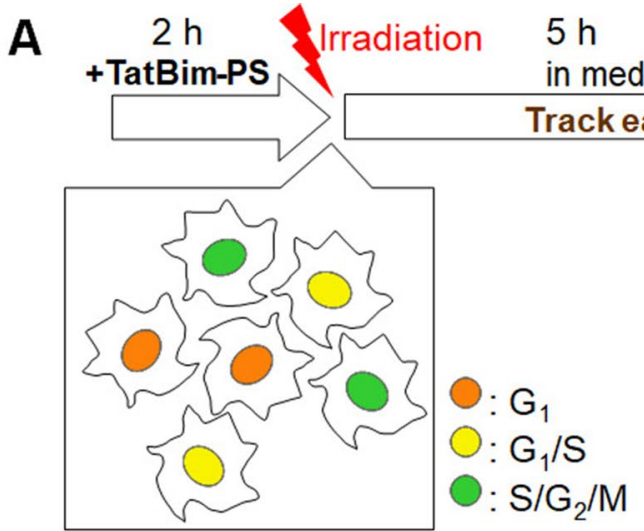

Fucci2

Cell cycle classification

B Time after Irradiation (h)
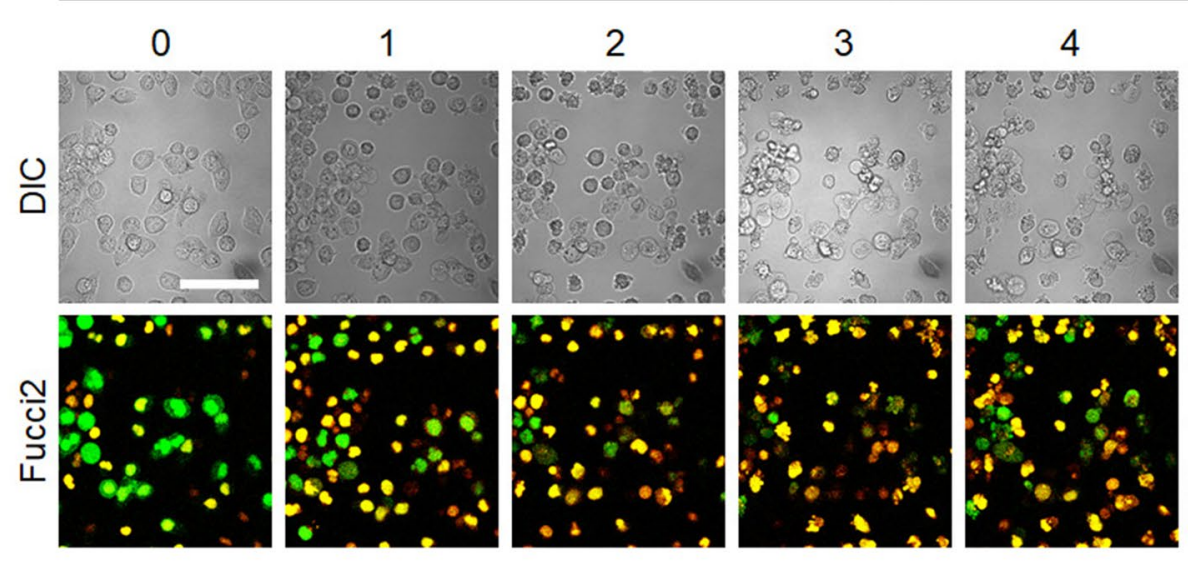

5 Apoptotic cell staining

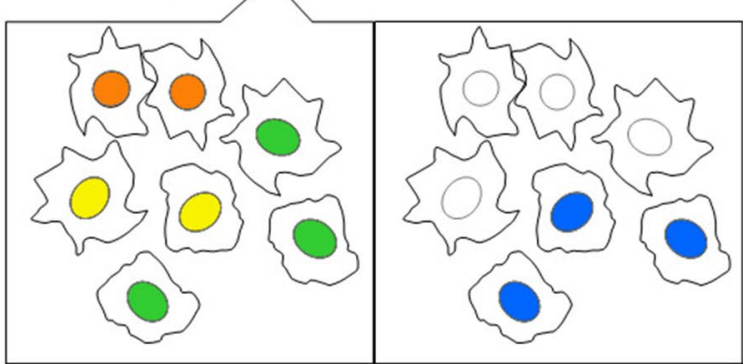

Fucci2

NucView405 $0.5 \mathrm{~h}$ $+N u c$ View 405 
4Figure 3. TatBim-PS induces apoptosis by photoirradiation most efficiently in the $\mathrm{G}_{1} / \mathrm{S}$ transition phase compared to that in other cell-cycle phases. (A) Scheme of the Fucci-PCI method to investigate cellcycle-dependent apoptosis. First, HeLa/Fucci2 cells were treated with TatBim-PS for $2 \mathrm{~h}$, and thereafter photoirradiated. Following the irradiation, the cells were incubated and time-lapse images were obtained using the same field of view. The cell cycle phase of each cell was classified using the cellular fluorescence images obtained immediately following the irradiation (left panel). Five hours after photoirradiation, apoptotic cells were stained with NucView405 for $30 \mathrm{~min}$. After the staining, blue NucView405 image (right panel) was captured at the same field as the left and middle panels. (B) Cell-cycle tracking every hour following photoirradiation (TatBim-PS internalization). (C) Light-dependent apoptosis of HeLa/Fucci2 cells at $5.5 \mathrm{~h}$ following photoirradiation. Scale bar, $50 \mu \mathrm{m}$. (D) Apoptosis rate of cells at each cell cycle phase. Data are shown as the mean \pm SEM $(n=3$; each of the analyzed areas included 111 cells on average). The $p$ value was determined by one-way ANOVA.

medium including thymidine was removed and the cells washed twice with serum-free RPMI 1640 medium. The cells were then treated with TatBim-PS for $2 \mathrm{~h}$ and irradiated as described above.

Statistical analysis. Student t-test was used for analyzing statistical differences between two groups. Comparison between more than two groups was performed by ANOVA followed by Fisher's test to determine significance of difference between all paired combinations. The $p$ values less than 0.05 were considered to be statistically significant.

\section{Results and discussion}

Photoinduced cytoplasmic dispersion of TatBim-PS at each cell-cycle phase. TatBim-PS was prepared by attaching Alexa Fluor 633 C5 maleimide, a photosensitizer, to the C-terminal Cys of the TatBim peptide. HPLC-purified TatBim peptide carried Alexa633 photosensitizer to the extent of 50\%; this was used as TatBim-PS in subsequent experiments.

HeLa/Fucci2 cells were treated with TatBim-PS for $2 \mathrm{~h}$. This procedure induces endocytosis and endosomal entrapment of TatBim-PS ${ }^{25}$. After the TatBim-PS treatment, the cells were irradiated at the excitation wavelength $(620 \pm 25 \mathrm{~nm})$ of the photosensitizer Alexa633 for inducing endosomal escape and cytoplasmic dispersion of TatBim-PS by the PCI mechanism ${ }^{13,25,26}$. We first evaluated the light dose-dependence of TatBim-PS cytoplasmic dispersion (Fig. S2); the light dose for TatBim-PS internalization by HeLa/Fucci2 cells was determined as $40 \mathrm{~J} /$ $\mathrm{cm}^{2}$. Immediately after the irradiation, the cells were imaged by confocal laser scanning fluorescence microscopy (Fig. 2A-D). The cell cycle phase of each cell was determined using Fucci2 imaging. Specifically, the cells displaying mCherry-hCdt1 fluorescence were classified as $\mathrm{G}_{1}$ (Fig. 2A), with the green fluorescence of mVenus-hGem were classified as $S / G_{2} / M$ (Fig. $2 B$ ), and cells displaying both orange and green fluorescence (yellow in the merged image (Fig. 2D)) were classified as G1/S; that is, in the transition state from G1 to S. Upon irradiation, cytoplasmic dispersion of Alexa633 fluorescence derived from TatBim-PS was confirmed in the majority of cells (Fig. 2C,E). We then analyzed cell cycle-dependence of the cytoplasmic internalization efficiency of TatBim-PS. Cytoplasmic internalization efficiency was over $95 \%$ for all cells in the three different cell cycle phases and did not markedly differ between the groups (Fig. 2F).

Cell cycle dependence of apoptosis induced by TatBim-PS. To investigate the cell-cycle dependence of TatBim-mediated apoptosis, HeLa/Fucci2 cells were tracked for $5.5 \mathrm{~h}$ following photoinduced cytosolic dispersion of TatBim-PS (Fig. 3A,B). The cell cycle phase of each cell was classified at the time point of $0 \mathrm{~h}$. Cell tracking was performed as shown in Figure S3. At $5 \mathrm{~h}$ after irradiation, apoptotic cells were stained for $30 \mathrm{~min}$ with NucView 405 Caspase-3 Substrate, which emits fluorescence in response to caspase-3/7 activity. Apoptotic cells were observed to occur in a light- (Fig. 3C) and photosensitizer- (Fig. S4) dependent manner, indicating that both light and the photosensitizer are necessary for TatBim-induced apoptosis. CCK- 8 , LDH, and JC- 1 assays supported that cell death (or decrease of cell viability) could be induced by TatBim-PS and light treatment, but not by photosensitizer Alexa633 and light treatment (data not shown). The phototoxicity was slightly observed (Fig. S4). However, this slight phototoxicity did not seem to significantly affect the cell cycle phase selectivity of TatBim-PS activity as the apoptosis ratio of irradiated cells differed less than $2 \%$ among the cellcycle phases (Fig. S4B). TatBim-PS induced apoptosis by photoirradiation in the $\mathrm{G}_{1} / \mathrm{S}$ transition phase $(47 \%)$ more efficiently than in the $\mathrm{G}_{1}(27 \%)$ and $\mathrm{S} / \mathrm{G}_{2} / \mathrm{M}(27 \%)$ phase (Fig. 3D). This result indicated that the cells in the $\mathrm{G}_{1} / \mathrm{S}$ transition phase exhibit high sensitivity to Bim-induced apoptosis. In contrast, no significant correlation was observed between TatBim-PS-induced apoptosis and cell cycle phase at $5.5 \mathrm{~h}$ following irradiation (Fig. S5), implying that the cell cycle phase is important for apoptosis induction only at the time point of cytoplasmic introduction of TatBim-PS but not subsequent time points.

Cell cycle synchronization with thymidine. To confirm that TatBim-PS efficiently induced apoptosis in the $G_{1} / S$ transition phase, we decreased the rate of $G_{1} / S$ transition phase cell formation using thymidine and examined the TatBim-PS-induced apoptosis rate of the HeLa/Fucci2 cells. Thymidine is a DNA synthesis inhibitor that can arrest cells at the $G_{1} / S$ boundary and, thus, it can synchronize cells at the $S$ phase after its removal. The cells treated with thymidine followed by $2 \mathrm{~h}$ TatBim-PS treatment were mainly detected in the $S / \mathrm{G}_{2} / \mathrm{M}$ phase rather than the $G_{1} / S$ transition phase (Fig. $4 A$ ). This result indicated that the thymidine-treated cells were mostly synchronized to the $\mathrm{S}$ phase, as described previously ${ }^{34,35}$. Specifically, Velichko et al. ${ }^{35}$ reported that HeLa cells are synchronized to the early $\mathrm{S}$ phase at $2 \mathrm{~h}$ following thymidine treatment, which is similar to the timing of 
A

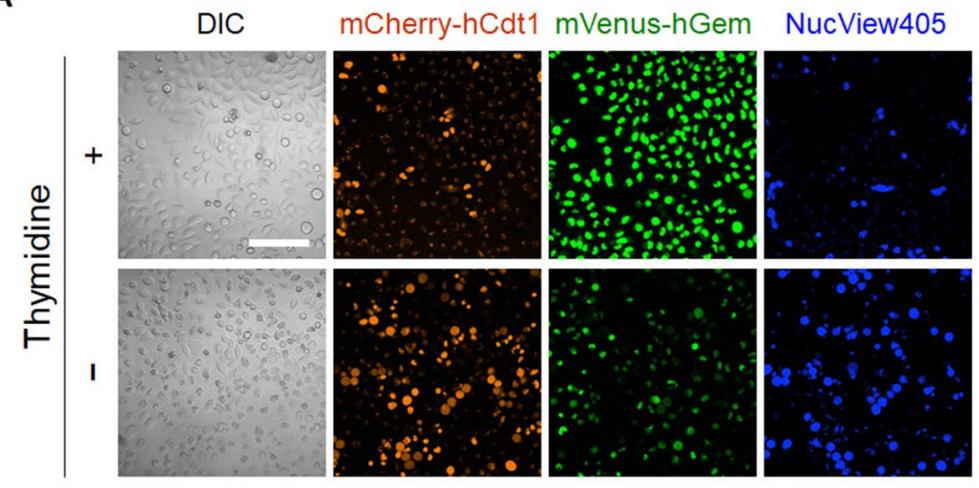

B

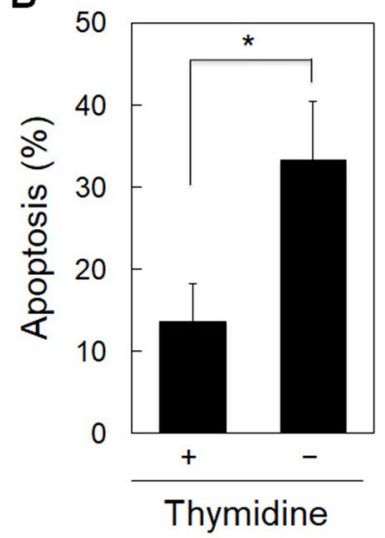

C

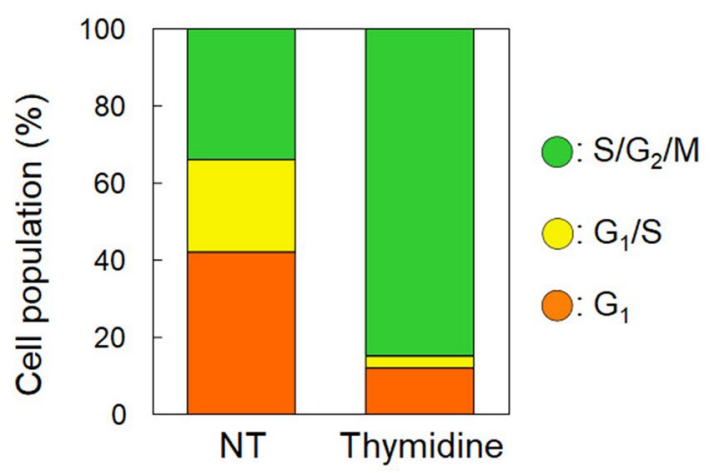

Figure 4. Decrease of cell population of the $\mathrm{G}_{1} / \mathrm{S}$ transition phase reduced the apoptosis rate. TatBim-PS induced apoptosis efficiently in the $\mathrm{G}_{1} / \mathrm{S}$ transition phase. (A) Cell cycle population and light-dependent apoptosis after treatment with thymidine. Scale bar, $50 \mu \mathrm{m}$. (B) Apoptosis rate after the treatment with thymidine. Data are shown as the mean \pm SEM $(n=3$; each of the analyzed areas included 123 cells on average). ${ }^{*} p<0.05$ by analysis of variance followed by Student's t-test. (C) Cell cycle population after thymidine treatment. Data are shown as the mean $(n=3$; each of the analyzed areas included 118 cells on average).

our cell cycle observations (approximately $2.2 \mathrm{~h}$ following thymidine treatment). The apoptosis rate among the total cells was significantly decreased from $33 \%$ (non-treated cells) to $14 \%$ (thymidine-treated cells) (Fig. 4B). As the rate of the $G_{1 /} S$ transition phase decreased to only $3 \%$ of the total cell number by the thymidine treatment (Fig. 4A), the observed reduced apoptosis rate in the thymidine-treated cells (Fig. 4B) supports the concept that TatBim-PS induces apoptosis more efficiently in the $\mathrm{G}_{1} / \mathrm{S}$ transition phase than in the other phases.

Bim and the $G_{1} / S$ transition phase. The reason why TatBim-PS-mediated apoptosis was enhanced in the $G_{1} / S$ transition phase remains unclear. Several reports indicate a relationship between Bim and the $G_{1} / S$ checkpoint. For example, deregulation of Cdk2, which is a key regulator of the $\mathrm{G}_{1} / \mathrm{S}$ checkpoint ${ }^{36,37}$, causes Foxo1 activation followed by Bim-mediated apoptosis ${ }^{38,39}$. Such pathways might be associated with the enhanced Bimmediated apoptosis in the $G_{1} / S$ transition phase. However, our experiments were initiated upon cellular internalization of Bim (TatBim-PS), which is located downstream of the $\mathrm{G}_{1} / \mathrm{S}$ checkpoint-related factors in the apoptosis pathway. Thus, it is difficult to consider that exogenous Bim affects an upstream factor (Cdk2 or Foxo1) which subsequently enhances Bim-mediated apoptosis. There might be some degree of feedback involved in the pathway.

Alternatively, Wan et al. ${ }^{40}$ reported that the Bim expression level increases during the $\mathrm{G}_{1}$ and early $\mathrm{S}$ phases compared to that in the late $S$ and $\mathrm{G}_{2} / \mathrm{M}$ phases. Although Bim upregulation is not $\mathrm{G}_{1} / \mathrm{S}$ transition phase-specific but also occurs in the $G_{1}$ phase, a difference of endogenous Bim concentration in each cell cycle phase might be related to the enhancement of TatBim-PS-mediated apoptosis in the $\mathrm{G}_{1} / \mathrm{S}$ phase. Thus, additional experiments such as the induction of Bim-mediated apoptosis in the presence of inhibitors of $\mathrm{G}_{1} / \mathrm{S}$ checkpoint-related factors or factors upregulated at the $G_{1} / S$ transition phases will be necessary to address the mechanisms underlying the observed effects.

Consideration of the methods for studying the cell cycle-dependence of peptide/protein functions. In this study, we analyzed the cell cycle-dependence of the apoptotic function of Bim peptide via the Fucci-PCI method based on Fucci2 imaging of PCI-treated (Bim peptide-introduced) cells followed by single cell tracking (Fig. 3). The target peptide (Bim) was conjugated with the Tat cell-penetrating peptide and a photosensitizer for PCI-mediated quick delivery into the cytosol. 
Compared to the method based on cell cycle synchronization (Fig. 4), the Fucci-PCI method presents several advantages, including: (1) the peptide function in every cell cycle phase can be analyzed under a single experimental condition; and (2) the undesired effects of cell cycle synchronizing reagents can be avoided. In contrast, a disadvantage of the Fucci-PCI method is that some phases (in the case of Fucci2, S, $\mathrm{G}_{2}$, and M phases) cannot be distinguished. In this study, the TatBim-PS/photo-induced apoptosis rate determined from the Fucci-PCI method was $27 \%$ in the majority of cell cycle phases except for in the $\mathrm{G}_{1} / \mathrm{S}$ transition phase (Fig. 3D), whereas the thymidine treatment reduced the apoptosis rate to a greater degree than expected (14\%) (Fig. 4B), possibly due to the undesired effects of thymidine other than the $S$ phase synchronization effect.

\section{Conclusion}

Cell cycle dependence of Bim peptide-induced apoptosis was successfully investigated using TatBim-PS and $\mathrm{HeLa} /$ Fucci2 cells. Upon photoirradiation, TatBim-PS was efficiently internalized by HeLa/Fucci2 irrespective of cell cycle stage. Apoptosis was most efficiently induced at the $G_{1} / S$ transition phase compared to that of $G_{1}$ and $S / G_{2} / M$ phases. S-phase synchronization by thymidine treatment decreased the cell population of the $G_{1} / S$ state and resulted in reduction of the apoptosis rate, demonstrating that the cells in the $G_{1} / S$ state are highly sensitive to Bim-mediated apoptosis. The Fucci-PCI method thus appears promising for analyzing the cell cycle dependence of functions of peptides/proteins (other than Bim). Although this study used HeLa/Fucci2 cells only, the Fucci-PCI method can be applied to numerous cell lines transformed by the commercially available Fucci gene. It is particularly easy to use already available Fucci-expressing cell lines, such as NMuMG/Fucci and COS/ Fucci in the RIKEN cell bank. Moreover, the system may also potentially be applied for studying the cell cycle dependence of RNA functions as a photoinduced cytoplasmic RNA delivery system has been developed ${ }^{27,41,42}$.

Received: 11 May 2020; Accepted: 16 September 2020

Published online: 05 November 2020

\section{References}

1. Matsui, Y., Staunton, D. E., Shapiro, H. M. \& Yunis, E. J. Comparison of MHC antigen expression on PHA- and MLC-induced T cell lines with that on T and B lymphoblastoid cell lines by cell cycle depedency. Hum. Immunol. 15, 285-301 (1986).

2. Larman, M. G., Saunders, C. M., Carroll, J., Lai, F. A. \& Swann, K. Cell cycle-dependent $\mathrm{Ca}^{2+}$ oscillations in mouse embryos are regulated by nuclear targeting of PLCל. J. Cell Sci. 117, 2513-2521 (2004).

3. Dalton, S. Linking the cell cycle to cell fate decisions. Trends Cell Biol. 25, 592-600 (2015).

4. Chan, C. Y. et al. Purinosome formation as a function of the cell cycle. Proc. Natl. Acad. Sci. 112, 1368-1373 (2015).

5. Terasima, T. \& Tolmach, L. J. X-Ray sensitivity and DNA synthesis in synchronous populations of HeLa cells. Science 140, 490-492 (1963).

6. Westra, A. \& Dewey, W. C. Variation in sensitivity to heat shock during the cell-cycle of chinese hamster cells in vitro. Int. J. Radiat. Biol. Relat. Stud. Phys. Chem. Med. 19, 467-477 (1971).

7. Matsumoto, Y. et al. Cell-cycle fate-monitoring distinguishes individual chemosensitive and chemoresistant cancer cells in drugtreated heterogeneous populations demonstrated by real-time FUCCI imaging. Cell Cycle 14, 621-629 (2015).

8. Marcus, J. M., Burke, R. T., Desisto, J. A., Landesman, Y. \& Orth, J. D. Longitudinal tracking of single live cancer cells to understand cell cycle effects of the nuclear export inhibitor. Sci. Rep. 5, 14391 (2015).

9. Kabouridis, P. S. Biological applications of protein transduction technology. Trends Biotechnol. 21, 498-503 (2003).

10. Mclenachan, S., Sarsero, J. P. \& Ioannou, P. A. Flow-cytometric analysis of mouse embryonic stem cell lipofection using small and large DNA constructs. Genomics 89, 708-720 (2007).

11. Sakaue-sawano, A. et al. Genetically encoded tools for optical dissection of the mammalian cell cycle. Mol. Cell 68, 626-640 (2017).

12. Liu, F., Wu, D., Wu, X. \& Chen, K. Analyses of the cell mechanical damage during microinjection. Soft Matter 11, 1434-1442 (2015).

13. Ohtsuki, T. et al. The molecular mechanism of photochemical internalization of cell penetrating peptide-cargo-photosensitizer conjugates. Sci. Rep. 5, 18577 (2015).

14. Berg, K. et al. Photochemical internalization: a novel technology for delivery of macromolecules into cytosol. Cancer Res. 59, 1180-1183 (1999).

15. Weyergang, A., Selbo, P. K., Berstad, M. E. B., Bostad, M. \& Berg, K. Photochemical internalization of tumor-targeted protein toxins. Laser. Surg. Med. 43, 721-733 (2011).

16. Mellert, K., Lamla, M., Scheffzek, K., Wittig, R. \& Kaufmann, D. Enhancing endosomal escape of transduced proteins by photochemical internalisation. PLOS ONE 7, e52473 (2012).

17. Gillmeister, M. P., Betenbaugh, M. J. \& Fishman, P. S. Cellular trafficking and photochemical internalization of cell penetrating peptide linked cargo proteins: a dual fluorescent labeling study. Bioconjug. Chem. 22, 556-566 (2011).

18. Jin, H. et al. Cytosolic delivery of LDL nanoparticle cargo using photochemical internalization. Photochem. Photobiol. Sci. 10, 810-816 (2011).

19. Norum, O.-J., Selbo, P. K., Weyergang, A., Giercksky, K.-E. \& Berg, K. Photochemical internalization (PCI) in cancer therapy: from bench towards bedside medicine. J. Photochem. Photobio. B. 96, 83-92 (2009).

20. Shiraga, K., Soe, T. H., Watanabe, K. \& Ohtsuki, T. Red and near-infrared light-directed cytoplasmic delivery of two different RNAs using photosensitive RNA carriers. Bioconjugate Chem. 29, 3174-3179 (2018).

21. Haug, M. et al. Photochemical internalization of peptide antigens provides a novel strategy to realize therapeutic cancer vaccination. Front. Immunol. 9, 650 (2018).

22. Meerovich, I., Muthukrishnan, N., Johnson, G. A., Erazo-Oliveras, A. \& Pellois, J.-P. Photodamage of lipid bilayers by irradiation of a fluorescently labeled cell-penetrating peptide. Biochim. Biophys. Acta. 1840, 507-515 (2014).

23. Yarani, R., Shiraishi, T. \& Nielsen, P. E. Effective photo-enhancement of cellular activity of fluorophore-octaarginine antisense PNA conjugates correlates with singlet oxygen formation, endosomal escape and chromophore lipophilicity. Sci. Rep. 8, 638 (2018).

24. Endoh, T., Sisido, M. \& Ohtsuki, T. Cellular siRNA delivery mediated by a cell-permeant RNA-binding protein and photoinduced RNA interference. Bioconjugate Chem. 19, 1017-1024 (2008).

25. Watanabe, K., Fujiwara, H., Kitamatsu, M. \& Ohtsuki, T. Photoinduced apoptosis using a peptide carrying a photosensitizer. Bioorg. Med. Chem. Lett. 26, 3115-3118 (2016).

26. Miyoshi, Y. et al. Endosomal escape of peptide-photosensitizer conjugates is affected by amino acid sequences near the photosensitizer. Bioconjugate Chem. 31, 916-922 (2020). 
27. Endoh, T., Sisido, M. \& Ohtsuki, T. Spatial regulation of specific gene expression through photoactivation of RNAi. J. Control. Release 137, 241-245 (2009).

28. Letai, A. et al. Distinct BH3 domains either sensitize or activate mitochondrial apoptosis, serving as prototype cancer therapeutics. Cancer Cell 2, 183-192 (2002).

29. Kashiwagi, H. et al. TAT-Bim induces extensive apoptosis in cancer cells. Ann. Surg. Oncol. 14, 1763-1771 (2007).

30. Kim, H., Kitamatsu, M. \& Ohtsuki, T. Combined apoptotic effects of peptide and miRNA in a peptide/miRNA nanocomplex. J. Biosci. Bioeng. 128, 110-116 (2019).

31. Fawell, S. et al. Tat-mediated delivery of heterologous proteins into cells. Proc. Natl. Acad. Sci. 91, 664-668 (1994).

32. Kristensen, M., Birch, D. \& Mørck Nielsen, H. Applications and challenges for use of cell-penetrating peptides as delivery vectors for peptide and protein cargos. Int. J. Mol. Sci. 17, 185 (2016).

33. Sakaue-sawano, A., Kobayashi, T., Ohtawa, K. \& Miyawaki, A. Drug-induced cell cycle modulation leading to cell-cycle arrest, nuclear mis-segregation, or endoreplication. BMC Cell Biol. 12, 2 (2011).

34. Vogel, W., Schempp, W. \& Sigwarth, I. Comparison of thymidine, fluorodeoxyuridine, hydroxyurea, and methotrexate blocking at the G1/S phase transition of the cell cycle, studied by replication patterns. Hum. Genet. 45, 193-198 (1978).

35. Velichko, A. K., Petrova, N. V., Razin, S. V. \& Kantidze, O. L. Mechanism of heat stress-induced cellular senescence elucidates the exclusive vulnerability of early S-phase cells to mild genotoxic stress. Nucleic Acids Res. 43, 6309-6320 (2015).

36. Neganova, I. et al. An important role for cdk2 in G1 to S checkpoint activation and DNA damage response in human embryonic stem cells. Stem Cells 29, 651-659 (2011)

37. Sherr, C. J. Cancer cell cycles. Science 274, 1672-1677 (1996).

38. Huang, H., Regan, K. M., Lou, Z., Chen, J. \& Tindall, D. J. Cdk2-dependent phosphorylation of FOXO1 as an apoptotic response to DNA damage. Science 314, 294-297 (2006).

39. Chae, H. D., Kim, B. M., Yun, U. J. \& Shin, D. Y. Deregulation of Cdk2 causes Bim-mediated apoptosis in p53-deficient tumors following actin damage. Oncogene 27, 4115-4121 (2008).

40. Wan, L. et al. APCCdc20 Suppresses apoptosis through targeting Bim for ubiquitination and destruction. Dev. Cell 29, 377-391 (2014).

41. Matsushita-ishiodori, Y., Kuwabara, R., Sakakoshi, H., Endoh, T. \& Ohtsuki, T. Photosensitizing carrier proteins for photoinducible RNA interference. Bioconjugate Chem. 22, 2222-2226 (2011).

42. Matsushita-Ishiodori, Y., Morinaga, M., Watanabe, K. \& Ohtsuki, T. Near-infrared light-directed RNAi using a photosensitive carrier molecule. Bioconjugate Chem. 24, 1669-1673 (2013).

\section{Acknowledgements}

This work was supported by JSPS KAKENHI Grant Number JP18H02090 (to T. O.). We thank Mr. S. Zhou (Okayama University) for his help in preparing TatBim-Alexa633.

\section{Author contributions}

T.O. designed the experiments. H. K. and S. W. performed experiments. M. K. synthesized the peptide materials. H. K., T. O., and K. W. wrote the paper.

\section{Competing interests}

The authors declare no competing interests.

\section{Additional information}

Supplementary information is available for this paper at https://doi.org/10.1038/s41598-020-76100-7.

Correspondence and requests for materials should be addressed to T.O.

Reprints and permissions information is available at www.nature.com/reprints.

Publisher's note Springer Nature remains neutral with regard to jurisdictional claims in published maps and institutional affiliations.

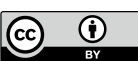

Open Access This article is licensed under a Creative Commons Attribution 4.0 International License, which permits use, sharing, adaptation, distribution and reproduction in any medium or format, as long as you give appropriate credit to the original author(s) and the source, provide a link to the Creative Commons licence, and indicate if changes were made. The images or other third party material in this article are included in the article's Creative Commons licence, unless indicated otherwise in a credit line to the material. If material is not included in the article's Creative Commons licence and your intended use is not permitted by statutory regulation or exceeds the permitted use, you will need to obtain permission directly from the copyright holder. To view a copy of this licence, visit http://creativecommons.org/licenses/by/4.0/.

(C) The Author(s) 2020 